\title{
Notes
}

\section{The Persistence of Dread in Law and Literature}

\author{
Gretchen A. Craft
}

Literature has its place in the study of law. The quiet taxonomy of the law library accommodates this presence in the basement, under call numbers LM for "legal miscellany" or Z for "miscellaneous non-legal material." There, interspersed among impractical or unclassifiable books of humor, reminiscence, and advice, stand Julius Caesar, The Fall, The Armies of the Night, The Palm at the End of the Mind, The Color Purple, the Oedipus cycle, and Billy Budd and Other Prose Pieces. ${ }^{1}$ The investigation of the relevance of such works to legal studies gained prominence in the early 1970's. Academics began to explore the intersection between the two disciplines, examining how legal concepts and procedures are used in literature, what literature has to teach lawyers, judges, and academicians, and what theories of literary criticism might reveal about the law. This Note argues, however, that law and literature are tied together not by their usefulness to each other, but by their shared preoccupation. They embody a response to relentless progress.

Dread is the fear of the unknown, the apprehension of a future heavy with the possibility of danger. Control or denial of this danger motivates much of human effort, in such areas as diverse as religion, medicine, meteorology, art, astrology, physics, gambling, and law. The existence of these pursuits reveals a passionate interest in understanding and affecting future events; each provides

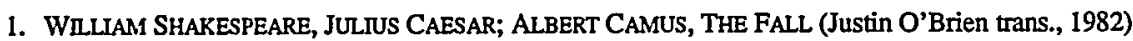
(1956); NORMAA MAILER, THE ARMIES OF THE NIGHT (1968); WALLACE STEVENS, THE PALM AT THE END OF THE MIND (Holly Stevens ed., 1971); ALICE WALKER, THE COLOR PURPLE (1982); SOPHOCLES, THE TheBAN Plays (E.F. Watling trans., Penguin Classics 1986); HeRMAN MELVILLE, BILY BudD AND OTHER PROSE PIECES (Raymond W. Weaver ed., 1924). 
a system for making sense of what might happen and for establishing rules to shape or predict possible outcomes. Because the human mind creates and seeks out patterns to lend order to unruly existence, fundamental concepts reverberate through disparate fields, resulting in unlikely combinations. Human endeavors abound in surprising recapitulations. The study of human cognition is related to plant classifications. ${ }^{2}$ Neurobiology is about memory. ${ }^{3}$ Theories about Neoplasticine art mirror legal commentary about the Equal Protection Clause. ${ }^{4}$ The outcomes of sports events affect the histories of nations. ${ }^{5}$ In this way, literature and law share a preoccupation that, though expressed differently by their specialized forms and dialects, unites them at the fundament.

In law and in literature, ubiquitous anxiety about the unknowable future exerts its force. While an examination of literature's overlap with law might focus on any number of interconnections (such as the uses of history, the structures of oppression, the frailty of human nature, or the influence of the parent-child relation on adult societal patterns), this Note juxtaposes the study of literature and law to expose their mutual preoccupation: an incurable fear of the future. Literature captures and suspends fear, allowing readers to contemplate the perils of arbitrary fate. Law, on the other hand, is an antidote to fate. It intervenes to provide explanation and remedy after something has happened. Dreadful anticipation, obscured generally by the tumult of everyday life, reveals itself in the clarity of literary and legal works which strip away the inessential to reveal the apprehensiveness of mankind. While dread is explicit in literature, it is implicit in law. Juxtaposing law with literature reveals a hidden function of law, the satisfaction of the desire to make sense of the future. This desire, evident in literature, propels the law's activities even as it is obscured by the law's structure.

Through a simultaneous simplification and imposition of meaning, works of literature and the process of law give solace to their audiences. The construction of a literary work necessarily orders the world it creates; its author must choose to include some details and omit others in the process of composition. The process of law, too, must filter events. Distilling the relevant from a sea of meaningful and meaningless details produces a simplicity that transforms events and subdues their inherent turmoil. In this way, both literature and law satisfy the yearning for coherent reality, mastery over chaos. The observation that literature and law are related neither suggests a possible improvement in legal procedure nor identifies a new theme in literature. However, in the process by which literature and law identify the essential and

2. See Brent Berlin, General Principles of Classification and Nomenclature in Folk Biology, 75 AM. ANTHROPOLOGIST 214 (1973).

3. See Oliver SACKS, THE MAN Who Mistook hIS WIFE FOR A HAT (1985).

4. See Laura S. Fitzgerald, Note, Towards a Modern Art of Law, 96 YALE L.J. 2051 (1987).

5. See RYSZARD KAPUSCINSKI, THE SOCCER WAR (William Brand trans., 1990). 
eliminate the inessential, the two disciplines illuminate an underlying human preoccupation with dread.

According to one view, law provides hard-nosed and practical methods to resolve disputes, to force subtleties into bright lines, to dissolve ambiguities, to define, balance, and clarify. But from another perspective, law's certainty appears a construction, imposed on elusive reality in an attempt to create order. Literature reveals what the law denies: there is no defense against the fateful tendencies of the world. Perhaps it is most accurate to say that literature and law are on separate paths, sometimes far apart, sometimes veering near to one another, both struggling with the same problem, yet never meeting.

\section{THE STUdY OF LAW AND Literature}

The recent development of the law-and-literature movement has added new perspectives to legal discussion. In a scheme which has been widely adopted by other scholars, Robert Weisberg identifies two branches in the law-literature enterprise: law-in-literature ${ }^{6}$ and law-as-

6. Robert Weisberg, The Law-Literature Enterprise, 1 YALE J.L. \& HUMAN. 1 (1988). Law-in-literature explores the use of legal procedures or concepts in literature. A limitation, however, is the scarcity of suitable subjects. The same authors appear repeatedly - the novelists Dickens, Twain, Dostoyevsky, Kafka, Faulkner, Melville, the poets Stevens, Auden, and Whitman, and the playwrights Shakespeare and Aeschylus-and their works have grown limp and shopworn under the examination of too many academics. Discussions that focus on the minutiae of legal procedure amidst the complexity of an entire work often seem reductive and hollow. See, e.g., David Conter, Eagleton, Judge Posner, and Shylock v. Antonio, 35 MCGILL L.J. 905 (1990); Jack W. Ledbetter, The Trial of Billy Budd, Foretopman, 58 A.B.A. J. 614 (1972).

The law-in-literature category also includes the popular argument that judges, lawyers, and legal scholars should study literature in order to infuse the law with emotion and empathy for the parties before the court See Robert A. Ferguson, The Judicial Opinion as Literary Genre, 2 YALE J.L. \& HuMAN. 201 (1990); Julius G. Getman, Voices, 66 TEX. L. REv. 577 (1988); Elizabeth Perry Hodges, Writing in a Different Voice, 66 TEX. L. REV. 629 (1988); Richard H. Weisberg, Family Feud: A Response to Robert Weisberg on Law and Literature, 1 YALE J.L. \& HUMAN. 69 (1988). Such critics argue that reading literature about the human condition, particularly literature involving legal themes, reminds legal practitioners of the human voice and the plight of the parties before the law. James Boyd White, one of the founders of the law-literature enterprise, explains that the law-literature movement insists "upon the reality of the experience of other people, and upon the importance of their stories, told in their words .... When we teach law properly, we teach a kind of literature as well . . . ." JAMES BOYD WHTTE, HERACLES' BOW 132 (1985). Law, its critics argue, is a heartless and faceless business, but literature serves to remind legal actors of the real consequences of the proceedings. In an enunciation of this view, Robin West counterposes "economic man," rational, benefitmaximizing and self-centered in the law and economics style, against "literary woman," empathic, complex and truth-seeking. Robin West, Economic Man and Literary Woman: One Contrast, 39 MERCER L. REV. 867, 868-73 (1988). Elsewhere, West argues that legal texts must be understood in relation to their powerful impact on their subjects. Robin West, Communities, Texts, and Law: Reflections on the Law and Literature Movement, 1 YALE J.L. \& HUMAN. 129, 155 (1988).

Others have criticized the argument that the study of literature will inspire judges and lawyers with a working empathy. While literature does communicate the profundity of another's experience, this understanding may not translate into a compassion for real people. See, e.g., Robert Weisberg, supra, at 17-18.

Commentators also promote the conflation of studies of law and literature to restore passion, as well as empathy, to the law. For example, Richard Weisberg encourages the study of literature to elevate the interest in the irrational aspects of human life. Richard Weisberg, supra, at 71-72. In a more specific exploration of the connection between passion and law, Paul Gewirtz uses an analysis of Oresteia to show how fury, suffering, and fear are at the heart of the legal order. He urges that these passions, most fully 
literature. ${ }^{7}$ While some of the most provocative discussions of law and literature consider themes that are central to both, such as revenge, judgment, or guilt, ${ }^{8}$ examples of this approach are surprisingly rare. Most work in law and literature places one discipline in the service of the other, either by treating law as one genre of literature, analyzed by literary criticism, or by using literature as an educational tool to produce better legal writing.

James Boyd White, a founder of the law-literature movement, claims that "the life of the law is thus a life of art, the art of making meaning in language with others." But law is not literature, constitutions are not art, and at the very least, lawyers are not poets. As these scholars repeatedly remind themselves, the connections between law and literature must not obscure the essential differences between the two fields. Each discipline operates within different ambits and achieves different goals. Reading Judge Cardozo's opinion in Hynes v. New York Central Railroad ${ }^{10}$ does not yield the same literary pleasure as reading Leo Tolstoy's novel Anna Karenina. Through ambiguity, selection, and suggestion, literature expresses a range of sensibility that scholarly work cannot achieve. Even a brief, isolated passage from a novel or play retains a power

explored in literature, must be allowed to assume their place beside reason. Paul Gewirtz, Aeschylus' Law, 101 HARV. L. REV. 1043, 1055 (1988).

7. Law-as-literature is bifurcated into two concerns: first, the examination of the style and rhetoric employed in legal writing, and second, the application of literary criticism to legal texts. Robert Weisberg, supra note 6 , at 36,42 . Two well-known proponents of the law-literature enterprise, James Boyd White and Judge Richard Posner, focus on the rhetoric of legal writing. White maintains that law is an art and that legal writing contains difficulties of a literary nature, such as character development, ambiguity, audience, and the problem of ending: "[T] he lawyer can be seen not only as a 'Thetorician' but also as a poet." WHITE, supra note 6, at xiii. Posner has a much less elevated sense of the importance of literature to law. He argues that because literary and legal success both depend on accomplished rhetorical style and persuasive power, the study of literature can aid the practice of law. RICHARD A. POSNER, LAW AND LITERATURE 275-89 (1988); Richard A. Posner, Law and Literature: A Relation Reargued, 72 VA. L. REV. 1351, 1378 (1986). For example, Posner compares the rhetorical power of persuasion in Yeats' poem The Second Coming to Justice Holmes' dissent in Lochner v. New York. Id. at 1378-83.

The second branch of law-as-literature addresses questions of interpretation and meaning. Here law and literature are studied together because both involve the creation and interpretation of texts, the examination of problems of ambiguity and intent, and the search for meaning. The application of literary criticism to legal works has generated numerous debates, as questions which preoccupy twentieth century literary critics now plague legal scholars as well: What does it mean to interpret a text? Can there be any meaning outside the reader's mind? What is the relationship between the words on the page and the original author's intent? The interpretation of the Constitution is at the heart of the debate, because its status as the central text of American law highlights the tension between the indeterminacy of language and the need for a common ground of understanding. For discussion of the problems of interpretation and meaning, see for example, RONALD DWORKIN, LAW'S EMPIRE (1986); Stanley Fish, Fish v. Fiss, 36 STAN. L. REV. 1325 (1984); Owen M. Fiss, Objectivity and Interpretation, 34 STAN. L. REV. 739 (1982); Sanford Levinson, Law as Literature, 60 TEX. L. REV. 373 (1982).

8. See, e.g., ThOMAS C. GREY, THE WALLACE STEVENS CASE (1991) (examining how poetry of Wallace Stevens illuminates principles and issues which pervade law); POSNER, supra note 7, at 25-70 (linking law and literature through revenge theme in The lliad, Michael Kohlhaas, Hamlet, and other works); Gewirt, supra note 6 (using Oresteia as starting point to discuss notions that passion, embodied in the play by the Furies, is necessarily incorporated into legal order, and that law is unavoidably gendered); Charles A. Reich, The Tragedy of Justice in Billy Budd, 56 YALE REv. 368 (1967) (using Melville's Billy Budd as springboard to examine concepts of innocence, punishment, and justice from both legal and "natural" perspectives).

9. WHITE, supra note 6 , at xii.

10. 131 N.E. 898 (N.Y. 1921). 
unavailable to a legal or literary exegesis. The Eumenides recounts the story of law's emergence from a tradition of blood vengeance. But no analytic description or discussion matches a passage from the play itself:

Untouched by lust for spoil, this court of law majestic, swift to fury, rising above you

as you sleep, our night watch always wakeful, guardian of our land-I found it here and now. ${ }^{11}$

And while literature describes, law prescribes. Robert Cover summed up this aspect of law in his succinct observation, "Legal interpretation takes place in a field of pain and death."'12 Wary of law's concentrated power, Margaret Jane Radin, too, cautions "against any easy metaphorical equation of law and literature, because of its tendency to obscure the violence of the law ... . Authoritative regulations command, not invite." ${ }^{\text {"13 }}$ Law has real consequences to real people. It cannot be ignored.

But despite these differences, there is something, some connection beyond the obvious facts that both are texts, both are the objects of necessary interpretation, both rely on the tension between clarity and ambiguity to carry out their meaning. There is an undeniable intersection of law and literature, a unity at the foundation that links the two disciplines. Each shapes the discussion according to its own method, but the same preoccupation haunts them both-a fear of the inevitable, incomprehensible future. Literature and law winnow out unimportant, distracting details through a process of elimination that reduces human experience, and shapes it, to achieve an account endowed with certainty and meaning.

\section{COMPOSITION THROUGH ElIMINATION}

Law and literature convey a simplicity lacking in actual life. This simplicity determines a framework of order through which daily life, a mass of chaotic and inconclusive facts, can be comprehended. Both disciplines seek to distill reality to its most essential elements, a process that results in a preternaturally vivid and immediate text. ${ }^{14}$ This paradox-that some parts of the truth must

11. AESCHYLUS, The Eumenides, in THE ORESTEIA lines 718-21 (R. Fagles trans., Viking Press 1975).

12. Robert M. Cover, Violence and the Word, 95 YALE L.J. 1601, 1601 (1986). See also Robin L. West, Adjudication is Not Interpretation: Some Reservations About the Law-As-Literature Movement, 54 TENN. L. REV. 203, 207 (1987).

13. Margaret Jane Radin, "After the Final No There Comes a Yes": A Law Teacher's Report, 2 YALE J.L. \& HUMAN. 253, 265 (1990).

14. This phenomenon is itself often the subject of comment in literature. A character wonders, "Why is a picture of something real eventually more exciting than the thing itself?" Jamaica Kincaid, Cold Heart, NEW YORKER, June 25, 1990, at 28, 38. In Roth's The Counterlife, just before a dentist and his assistant begin an affair, they pretend to be a dentist and an assistant having an affair. "It was, it was wild, it made us crazy -it was the strangest thing I'd ever done. We did it for weeks, pretended like that, and she kept saying, "Why is it so exciting when all we're pretending to be is what we are?" God, it was great!" PHIIIP 
be eliminated to reveal its essence-is at the center of both the literary and legal processes. Filtration, simplification, is an attempt to cut to the heart of things. Robert Cover's description of this transformation applies to both law and literature: "Narratives are models through which we study and experience transformations that result when a given simplified state of affairs is made to pass through the force field of a similarly simplified set of norms."15 Simplification transforms the truth, particularly its emotional aspect; it exposes some elements while throwing others into shadow. For both disciplines, the filtration process is driven by a demand for order and connections, for composition.

\section{A. Omission and Inclusion}

Literature, itself the product of filtration, cannot escape the inevitable relevance of its every detail; each element, once included, takes on significance merely because of its presence in the text. Not even a deliberate attempt on the part of an author to inundate the reader with random or over-inclusive detail can thwart this process. ${ }^{16}$ Art lies in the suggestive construction of detail. ${ }^{17}$ The deliberate accumulation of facts creates a convincing fiction, in which a single detail may illuminate an entire work: the sound of rain, ${ }^{18}$ fresh candles late at night, ${ }^{19}$ the scent of ginger, ${ }^{20}$ one brief comment. "Do you always watch for the longest day of the year and then miss it? I always watch for the

ROTH, THE COUNTERLIFE 34-35 (1986). Similarly, Derrida notes the repetition of the title, "Before the Law," in the first line of that story by the same name: "[T]hese words come to signify something else entirely, perhaps even the opposite of the title that nevertheless reproduces them ...." JACQUES DERRIDA, Before the Law, in ACTS OF LITERATURE 181, 201 (Derek Attridge ed., 1992).

15. Robert Cover, The Supreme Court 1982 Term-Foreword: Nomos and Narrative, 97 HARv. L. REV. 4, 10 (1983).

16. For examples of works that manipulate the element of detail, see JAMES JOYCE, ULYSSES (The Modem Libr. 1961) (1922); LAURENCE STERNE, THE LIFE AND OPINONS OF TRISTRAM SHANDY, GENTLEMAN (Clarendon Press 1983) (1767); KURT VONNEGUT, JR., BREAKFAST OF CHAMPIONS (1973).

17. Virginia Woolf discussed this problem of authorship: "I mean to eliminate all waste, deadness, superfluity: to give the moment whole; whatever it includes .... Waste, deadness, come from the inclusion of things that don't belong to the moment...." VIRGINIA WOOLF, A WRITER's DIARY 136 (Leonard Woolf ed., 1953).

18. "The downpour fell with the heavy uninterrupted rush of a sweeping flood, with a sound of unchecked overwhelming fury that called to one's mind the images of collapsing bridges, of uprooted trees, of undermined mountains." JOSEPH CONRAD, LORD JM 136 (Signet Classic 1981) (1899).

19.

After he had gone [Isabel] leaned back in her chair and closed her eyes; and for a long time, far into the night and still further, she sat in the still drawing-room, given up to her meditation. A servant came in to attend to the fire, and she bade him bring fresh candles and then go to bed. Osmond had told her to think of what he had said; and she did so indeed, and of many other things.

HENRY JAMES, THE PORTRATT OF A LADY 354 (Robert D. Bramberg ed., W.W. Norton \& Co. 1975) (1881).

20.

On autumn nights, in some parts of the city, the wind from the lake brings a sweetish smell to shore. An odor like crystallized ginger, or sweet iced tea with a dark clove floating in it. There is no explanation for the smell either, since the lake ... was so full of mill refuse and the chemical wastes of a plastics manufacturer that the hair of the willows that stood near the shore was thin and pale.

TONI MORRISON, SONG OF SOLOMON 185 (1977). 
longest day in the year and then miss it." 21 In literature, events, characters, landscapes, and emotions are both determined and ordered by the hand of the author. Jacques Derrida includes this quality, that "events are related," in his list of the fundamental presuppositions underlying literature. ${ }^{22}$ Although Derrida discusses this characteristic with regard to literature and argues that many relations are not literature in this sense, law, too, composes events and facts.

Law also imposes order on crowded facts through its hierarchy of relevance. Orderly rules regulate what can and cannot be considered germane to the conflict before the court. ${ }^{23}$ By forcing all facts to conform to the requirements of relevance, admissibility, materiality, and sufficiency, ${ }^{24}$ a court limits the scope of the information it considers. Through elimination, the law obscures some facts and exaggerates others to purge the proceeding of inessentials. This distortion, though necessary, is subject to great error, and is itself a frequent object of legal controversy. Karl Llewellyn warned against distortion in his description of a lawyer: "A lawyer, and as such prone without thought to twist analogies, and rules, and instances, to his conclusion. A lawyer, and as such peculiarly prone to disregard the implications which do not bear directly on his case."25 The danger, of course, is that simplification will eliminate essential elements and thus undermine the justice of the proceeding. As one commentator notes, the court is not pursuing the truth generally, but only the truth that specifically relates to the controversy before $i^{26}$ The court must narrow and flatten the truths it considers in order to provide a coherent, controlled outcome.

\section{B. The Presence of Emotion}

Raw emotion is a chief object of filtration in the law; the court translates passionate reality into its own formal, reserved language. Scholars who draw distinctions between law and literature decry the legal process's suppression of its emotional content. While literature painstakingly details the inner experience of its subjects, law, critics claim, lacks empathy or understanding. ${ }^{27}$ Such critics want mercy and understanding in the place of blind, unfeeling enforcement. Although lawyers present the emotional aspects of a case in the courtroom, the artifact that survives appears, at first glance, bloodless and narrow.

Nevertheless, the transmuted product retains its original passion, subdued but still powerful. Even the most dry rendition of an event provides enough hints

21. F. SCOTT FTtZgerald, THE GREAT GATSBY 12 (Charles Scribner's Sons 1953) (1925).

22. DERRIDA, supra note 14 , at 186.

23. See, e.g., FED. R. EVD. 401-03. (1986).

24. Keith Burgess-Jackson, An Epistemic Approach to Legal Relevance, 18 ST. MARY's L.J. 463, 465

25. KARL N. LleWELLYN, THE BRAMBLE BuSH 44 (3d ed. 1991) (1930).

26. Burgess-Jackson, supra note 24 , at 472.

27. See supra note 6. 
for an alert reader to discern this hidden content. The judicial opinion's solemn tone, formal language, and reticence allow the reader to withstand the pain of empathy. Legal critics want the raw and unmodified "human voice," but unfiltered pain may overwhelm participants. The system cannot allow bystanders to be consumed by what they must watch, so it preserves distance through dispassionate language. Llewellyn explains the tension between compassion and consuming pity:

Life is so full of pain, so instinct with trouble, that in a mere effort to keep going we have either to shut ourselves in from suffering, to keep from seeing it, or else to dull our sensitivity. The latter is the rule when we are called upon to do our work with social pain. To give oneself wholly to one's case is to burn oneself up. But to condition oneself against the burning is to set the ruts for jading. ${ }^{28}$

Martha Minow criticizes legal discourse's formal and scientific vocabulary, which describes an injury as cerebral hemorrhage or hematoma instead of as "pools of rotted blood inside his brain." 29 Both descriptions are accurate, but, she maintains, judges use formal language to distance themselves from the emotions aroused by cases. But participants must be allowed to contain the passion, or else burn up in the suffering. When Justice Blackmun wrote, "Poor Joshua!" the DeShaney case broke open. ${ }^{30}$ Here the anguish was confronted and experienced, and something essential-pity-was given voice. But such unfiltered emotion, in case after case, would jade observers' sympathy and distort even the attempt at impartiality. Distance may be a necessary part of compassionate judging. Adam Smith describes the tension between the sufferer's longing for sympathy and the spectator's necessary distance from that pain:

The [sufferer] principally concerned ... passionately desires a more complete sympathy. He longs for that relief which nothing can afford him but the entire concord of the affections of the spectators with his own ... violent and disagreeable passions .... But he can only hope to obtain this by lowering his passion to that pitch, in which the spectators are capable of going along with him. He must flatten ... the sharpness of its natural tone, in order to reduce it to harmony and concord with the emotions of those who are about him. ${ }^{31}$

By "flattening" the sharpness of the pain, the sufferer eases the burden of the audience. And at the same time that the spectator sympathizes with the

28. LLEWELLYN, supra note 25 , at 145.

- 29. Martha Minow, Words and the Door to the Land of Change: Law, Language, and Family Violence, 43 VAND. L. REV. 1665, 1673 (1990).

30. DeShaney v. Winnebago County Dep't of Social Servs., 489 U.S. 189, 213 (1989) (Blackmun, J., dissenting). The case held that state social workers did not violate a child's constitutional rights when they failed to remove him from the custody of his father who severely beat him.

31. 1 ADAM SMITH, THE THEORY OF MORAL SENTIMENTS 39 (London, Strahan \& Cadell 1797). 
sufferer, the sufferer places himself or herself in the place of the spectator. This mutual sympathy restores a measure of tranquillity to the sufferer by providing perspective on his or her own plight. ${ }^{32}$ In a legal setting, then, this distance from suffering benefits all parties before the court. So many people participate in the perfection of the law; the full force of each individual's life and troubles, if not "flattened," would soon exhaust them.

Law must confront the actual and provide a method to decide what is relevant from among the vast number of facts. The student of the law must supply the emotion and perceive the unspoken. Llewellyn compared this process to the writing of fiction or dramatizing: "[T]o [visualize the facts] will require you to loose your imagination - but with discipline; will require you first to feel yourself into the situation as depicted and then to see, to feel the texture and the rough knobs of each fact." ${ }^{33}$ Even if the judge writing the opinion has seemed to squash deliberately the vitality of a case, its facts will allow careful readers to replace the emotion. Seemingly absent passions are present, but muted by $\$$ their new form. ${ }^{34}$

Many critics denounce the distancing process as an evasion, a deliberate ignorance. ${ }^{35}$ Julius Getman voices this argument in his account of a classroom exchange on State $v$. Williams. ${ }^{36}$ The case concerned a Native American couple found guilty of negligent homicide of their seventeen-month old son for whom they failed to provide medical attention.

The class discussed the opinion largely in professional voice, until a black woman student from South Carolina, who rarely spoke, tried to explain the couple's motives. She said, "I don't know about Native Americans, but I know why black people in South Carolina often avoid doctors." She then described in moving and personal terms, "the feeling of being treated like an object and looked at as though you aren't human." ${ }^{37}$

32. Id. at 41 . Smith argues that the exchange of sympathies between the passionate sufferer and the more distant spectator serves to console the sufferer:

[A]s the reflected passion ... is much weaker than the original one, it necessarily abates the violence of what he felt before [the sufferer] came into their presence, before he began to recollect in what manner they would be affected by it, and to view his situation in this candid and impartial light.

33. LLEWELLYN, supra note 25 , at 64 .

34. For an enunciation of the argument that the law represses the passions, see Robin West, Love, Rage and Legal Theory, 1 YALE J.L. \& FEMINISM 101 (1989).

35. Mari Matsuda argues:

Abstraction and detachment are ways out of the discomfort of direct confrontation with the ugliness of oppression. Abstraction, criticized by both feminists and scholars of color, is the method that allows theorists to discuss liberty, property, and rights in the aspirational mode of liberalism with no connection to what those concepts mean in real people's lives.

Mari J. Matsuda, When the First Quail Calls: Multiple Consciousness as Jurisprudential Method, 11 WoMEN's RTS. L. REP. 7, 9 (1989).

36. 484 P.2d 1167 (Wash. Ct. App. 1971) (holding parents' failure to obtain proper medical attention for child constituted negligence sufficient to sustain conviction for manslaughter).

37. Getman, supra note 6 , at 583 . 
The student's comment convinced Getman that if the court had understood the couple's feelings as his student described them, the couple would not have been convicted. At the same time, her observation reminded him of the importance of presenting the client's human voice.

In a response, Mark Yudof uses Getman's example to illustrate the danger of relying on the human voice in the law. He points out that the student may have misrepresented the reasons for the couple's behavior; her empathy may be misplaced. Further, Yudof asks: "But let us suppose that Professor Getman and his student are right and that this particular human voice gives us insight into the motivations and thinking of the Williams defendants. Should the parents have been found not guilty of negligent homicide?"38 Yudof argues for the importance of including the voice of the dead child, as well as the loving but negligent parents, and for the importance of forging a law that will compel all parents to provide necessary medical attention for their children. Resolution and order require distance from the many clamoring voices.

Despite their disagreement in interpreting the case, both Getman and Yudof implicitly assume for their arguments that the court's opinion is distant and bereft of human emotion. And, in fact, the opinion is not an emotional, highly charged rendition of the facts and issues. It includes lengthy, dry discussions of the definition of willful misconduct, ordinary caution, and the statutory duties of parents, with a spare account of the facts. But, despite its distant tone, the court's opinion preserves the anguish of those involved. That element has its place: the couple's love and affection for the baby, their fear of authority's intervention, their pitiful decision not to take the baby to a doctor but to try to cure him with aspirin. The court reports:

Defendant husband testified that "the way the cheek looked ... they would think we were neglecting him and take him away from us and not give him back." Defendant wife testified that the defendants were "waiting for the swelling to go down," and also that they were afraid to take the child to a doctor for fear that the doctor would report them to the welfare department who, in turn, would take the child away. "It's just that I was so scared of losing him. ${ }^{.39}$

The court also describes the baby's abscessed tooth, his swollen, bluish cheek, and the smell of gangrene which hovered over his head for ten days before he died. The law has filtered the events to allow its witnesses to bear the powerful emotional content of the case. The reader sees that the parents, though loving, made a terrible and irreversible mistake. Perhaps this case should have been decided differently. Perhaps the court filtered the facts in the wrong way, and

38. Mark G. Yudof, "Tea at the Palaz of Hoon": The Human Voice in Legal Rules, 66 TEX. L. REV. 589,600 (1988).

39. State v. Williams, 484 P.2d at 1174 . 
reached the wrong conclusion in finding the couple guilty of statutory manslaughter. But whatever the result, the shock, the pity for the child and for the parents, is included in the case, now in the flattened language of the law. The bland pages of the Pacific Reporter contain that passion. And whether the decision was right or wrong, there is an end. The last line of the case satisfies the need for finality: "The judgment is affirmed." ${ }^{\text {*0 }}$ Perhaps it is the reader, reading the case later, who imagines the emotional content in the case; and yet that content cannot be taken out. Despite the flat language, the legal terminology, and the lists of precedent and authority, we feel the pain of the case. Something senseless happened: a child died of a bad tooth.

Human suffering and dispute must be resolved in a framework in which the progress toward resolution will not disrupt the attendants who wish to help. They must not burn up in the passion, the anguish, the misfortune. Gerald Wetlaufer describes the tone taken by lawyers, judges, and legal scholars as "objective, neutral, impersonal, authoritative, judgmental, and certain." formal voice allows the necessary distance from pain. In another case, where a seven-year-old boy became trapped between a building elevator's outer door and shaft wall, the court writes:

[T]he officers worked for four and one-half hours to free the child. While their efforts continued, the plaintiff watched as her son moaned, cried out and flailed his arms. Much of the time she was restrained from touching him, apparently to prevent interference with the attempted rescue. The child suffered multiple bone fractures and massive internal hemorrhaging. He died while still trapped, his mother a helpless observer. $^{42}$

Despite the restrained language, the reader feels the true content of the case. Elsewhere, a woman was boarding a bus when the doors closed on her right hand and left foot and dragged her along the pavement. The court notes,

Plaintiff is crippled and will suffer pain for life. Although this pain could, perhaps, be alleviated by an operative fusion of the ankle, the doctors considered and rejected this procedure .... The foot is not only permanently deformed but has a persistent open ulcer on the heel, there being a continuous drainage from the entire area. Medical care of this foot and ankle is to be reasonably expected for the remainder of plaintiff's life. ${ }^{43}$

40. $l d$.

41. Gerald B. Wetlaufer, Rhetoric and Its Denial in Legal Discourse, 76 VA. L. REv. 1545, 1568-69 (1990) (citations omitted).

42. Portee v. Jaffee, 417 A.2d 521, 522-23 (N.J. 1980) (determining that parent can recover damages for emotional anguish after watching child die due to negligence).

43. Seffert v. Los Angeles Transit Lines, 364 P.2d 337, 341 (Cal. 1961) (en banc) (citation omitted) (holding nonpecuniary damages awarded by lower court not excessive). 
The descriptions of plaintiffs' injuries are no less horrifying because they are catalogued in formal, medical language.

\section{Restraint Bestows Dignity and Immediacy}

Critics ignore how tenderly the law cares for the individuals caught up in the particular, the actual plight. Just as in literature characters command the sustained attention of the author and an audience of readers, the legal system devotes its attention to the parties and preserves their stories. The court recites their particularities. "On September 23, 1978, on Interstate Highway 80 in Solano County, California, Gary Zurcher lost control of his Honda motorcycle and collided with a tractor. Zurcher was severely injured, and his passenger and wife, Ruth Ann Moreno, was killed."44 Everyone's name is known-plaintiff, defendant, lawyers, and judge-and their individual stories are valuable and historical. The court's opening moments emphasize the importance of each voice: Come forward, and you shall be heard.

Just as one goal of literature is to "include nonsense, fact, sordidity: but made transparent,"45 law includes any predicament that comes before the bar, giving it a forum, a universal shape. By enforcing a simplified and formalized version of events, the law dignifies even the smallest disputes. All desires and complaints receive grave attention. The law does not blink at a superabundance of raisin boxes, ${ }^{46}$ or overly specific tastes in wrought-iron piping, ${ }^{47}$ or the oxymoron of two ships Peerless. ${ }^{48}$ Attachment to worldly things is honored: a brand-new fur coat on sale for one dollar, ${ }^{49}$ an order of carpets, ${ }^{50}$ the profits from a recipe of fruit flavored ice cream. ${ }^{51}$ Undignified situations are treated with respect. ${ }^{52}$ Even a class action suit against Satan for civil rights violations deserves its time in court, its record, docket number, keynote, and a solemn

44. Asahi Metal Indus. Co. v. Superior Court, 480 U.S. 102 (1980) (reversing California Supreme Court's finding of personal jurisdiction over Japanese tire valve manufacturer).

45. WOOLF, supra note 17 , at 136.

46. See United States v. Braunstein, 75 F. Supp. 137, 138 (S.D.N.Y. 1947) (finding that error-ridden reply to offer for purchase of raisins did not constitute valid acceptance).

47. See Jacob \& Youngs, Inc. v. Kent, 129 N.E. 889, 890 (N.Y. 1921) (finding that unintentional installation of non-preferred but equivalent brand of pipe did not constitute breach of contract).

48. See Raffles v. Wichelhaus, 159 Eng. Rep. 375 (Ex. 1864) (holding that defendant was not obligated to accept delivery of goods from ship Peerless arriving in October when defendant intended purchase from different ship Peerless arriving in December).

49. See Lefkowitz v. Great Minneapolis Surplus Store, 86 N.W.2d 689, 690 (Minn. 1957) (finding that explicit, non-negotiable offer of sale in newspaper constituted contractual offer).

50. See Crook v. Cowan, 64 N.C. 627 (1870) (finding that contract for carpets was completed once specific order for goods had been filled).

51. See Davis v. General Foods Corp., 21 F. Supp. 445, 446 (S.D.N.Y. 1937) (finding that defendant's letter retaining complete discretion for use of plaintiff's idea for ice cream did not give rise to binding obligation).

52. See Doutre v. Niec, 138 N.W.2d 501, 502 (Mich. Ct. App. 1965) ("Defendants operate a beauty shop in Flint. On April 19, 1962 plaintiff was given a bleach and color treatment by defendants without a pretreatment patch test. Plaintiff received head and facial injuries as a result of the treatment and sued for damages.") 
dismissal by a judge-due to questions of personal jurisdiction over the defendant, propriety of class action, and problems of service of process. ${ }^{53}$ So too with a plaintiff seeking, among other things, $\$ 400$ trillion in damages both from Pan Am for grand theft with the intent to commit nuclear sabotage and from Dr. Martin Luther King's widow due to her threat to the Roman Catholic Church and its episcopacy. ${ }^{54}$ A district court and, later, an appeals court reviewed these charges and placed them within the legal framework: dismissal under Fed. R. Civ. P. 12(b)(6). ${ }^{55}$ We have our response.

The dignity of legal language prevents pathos from edging into bathos. One minute, fourteen-year-old Cynthia Steinhauser was travelling down the highway with her parents. A few minutes later, after a minor collision between the family's car and an oncoming car, something had happened.

[W]ithin a few minutes after the accident Cynthia began to behave in an unusual way. Her parents observed her to be "glassy-eyed," "upset," "highly agitated," "nervous," and "disturbed." When Ponzini [the driver of the other car] came toward the Steinhauser car, she jumped up and down and made menacing gestures until restrained by her father. ${ }^{56}$

The accident had triggered a psychotic reaction, and within a few weeks, Cynthia was hospitalized as a schizophrenic. The court's solemn, factual delivery dignifies the grotesque picture of a girl "jumping up and down," transformed. In a different case, about a fight and its aftermath, the reader may think that the court's account is unfeeling and cold. In fact, the details provide just enough information to evoke pity and dismay at the actions of a well-intentioned but foolish friend:

Siegrist escaped unharmed, but Farwell was severely beaten. Ice was applied to Farwell's head. Siegrist then drove Farwell around for approximately two hours, stopping at a number of drive-in restaurants. Farwell went to sleep in the back seat of his car. Around midnight Siegrist drove the car to the home of Farwell's grandparents, parked it in the driveway, unsuccessfully attempted to rouse Farwell, and left. Farwell's grandparents discovered him in the car the next morning and took him to the hospital. He died three days later of an epidural hematoma. ${ }^{57}$

53. See United States ex rel. Mayo v. Satan, 54 F.R.D. 282 (W.D. Pa. 1971).

54. See Windsor v. Pan American Airways, 744 F.2d 1187, 1188 (5th Cir. 1984) (dismissing a "patently frivolous" suit).

55. Id.

56. Steinhauser v. Hertz Corp., 421 F.2d 1169, 1170 (2d Cir. 1970) (finding that lower court's jury instructions should have allowed consideration of medical evidence to support possibility of trauma-induced schizophrenia).

57. Farwell v. Keaton, 240 N.W.2d 217, 219 (Mich. 1976) (finding that decedent's companion was liable for wrongful death). 
The juxtaposition of Siegrist driving from one hamburger joint to the next while his friend lay dying on the back seat is almost morbidly comic, but the court's removed presentation minimizes that reaction.

The court's tone provides relief from the pain contained within the opinion. Private suffering is not disguised, but dignified. Whitehead, ill, frantic, worried about his money and his sick wife, implored his niece and her husband to come help him sort out his affairs. "If I had you here my mind would get better and my courage return, and we could work things out." They responded with a telegram: "Cheer up-we will soon be there, we will wire you from the train." Too late. Five days later, he committed suicide; his wife died less than six weeks later. The restraint of the court makes this account bearable, yet it includes the details that make it a powerful story.

The elimination of interesting and perhaps relevant details often protects the parties. Many legal opinions tantalize the reader with their suggestive, minimal facts. In one case, Miss Blanche Josephine Schweizer of New York and Count Oberto Giacomo Giovanni Francesco Maria Gulinelli of Italy got married, were promised $\$ 2,500$ a year by her father, and sold the right to receive that money. The court addresses the issue of whether there was any consideration for the promised annuity. No prying questions asked. ${ }^{59}$ Elsewhere, the court does not speculate about the relationships among Anna Feinberg, the invaluable assistant treasurer, company president Max Lippman, who persuaded the board of directors to give her a raise and a lifetime pension, Max Lippman's widow, who became president after her husband died and who fussed about the monthly pension checks, or the widow's son-in-law who, once he became president, ceased payments. ${ }^{60}$ In another case, Dr. Eddingfield refused to treat a former patient, Hurley, when Hurley became dangerously ill. The doctor was not asked why he refused treatment, even though he was not busy, was offered a fee in advance, and knew that no other physician was available. He did not have to explain himself. ${ }^{61}$ The legal process controls crisis, in part, by restricting the scope of the facts and issues before it; these limits securely separate the significant and public elements of a conflict from the personal and private. The tone of legal writing, and the material it omits, accommodate the need for the parties' dignity and the readers' detachment.

Despite the fact that literature and law each select and eliminate from an infinitude of possible details, or because of it, the two disciplines present a clarity

58. Davis v. Jacoby, 34 P.2d 1026, 1028 (Cal. 1934) (reversing judgment refusing to grant specific performance of alleged contract to make will).

59. De Cicco v. Schweizer, 117 N.E. 807 (N.Y. 1917) (holding marriage to be adequate consideration for father's promise of annuity).

60. Feinberg v. Pfeiffer Co., 322 S.W.2d 163 (Mo. Ct. App. 1959) (holding plaintiff's retirement from lucrative position in reliance upon defendant's promise to pay life pension constituted consideration).

61. Hurley v. Eddingfield, 59 N.E. 1058 (Ind. 1901) (holding physician not liable for refusing to treat patient). 
lacking in ordinary life. What Lukács observed about literature is also true of the law:

This twofold labour creates a new immediacy, one that is artistically mediated; in it, even though the surface of life is sufficiently transparent to allow the underlying essence to shine through (something which is not true of immediate experience in real life), it nevertheless manifests itself as immediacy, as life as it actually appears. ${ }^{62}$

Whether reading a novel or reading a case, the reader is struck by an experience which seems more vivid than real life. Law and literature create this startling immediacy through the manipulation of experience. A few lines of a case present a dangerous and bleak landscape: "[U]pon a certain wild and uninhabited, unpossessed and waste land, called the beach, [the defendant did] find and start one of those noxious beasts called a fox. ${ }^{, 63}$ Both describe the inevitable unfolding of events, sometimes marked by surprise or sudden twists, but following an inexorable progress. "[Wisdom's] interest lies in leading to the conclusion you are headed for. You shape its words, its context, to an end decreed."64 Law and literature draw strange proportions; minor details loom and major facts recede. A case may turn on a single word or the meaning of a simple action, on the implications of the word "subject" dropped from a telegram, ${ }^{65}$ on whether a brother-in-law intended to make a gift or a bargain when he offered a home to his sister-in-law, ${ }^{66}$ on whether two friends knew that one of them was joking when he offered to sell his horse for five pounds. ${ }^{67}$ Time compresses or accelerates. In a short story, the desire to dress in finery is discussed for many pages, while a decade is summed up in a single line: "And this life lasted for ten years." ${ }^{.68}$ Fiction is a construction of facts through which an author controls a reader's experience. Law, too, is founded on a composition of facts-real facts that are filtered through the sieve, not of imagination, but through a standard of legal relevancy.

62. George Lukás, Realism in the Balance, in AEsTHETICS AND PoLITICs 28, 39 (Rodney Livingstone trans., N.L.B. 1977) (1938).

63. Pierson v. Post, 3 Cai. R. 175, 175 (N.Y. 1805) (holding that pursuit of fox by hunter did not create property right).

64. LLEWELLYN, supra note 25 , at 43.

65. Butler v. Foley, 179 N.W. 34, 35 (Mich. 1920) (noting that party who chooses telegraph company as its means of communication designates company its agent and therefore is responsible for any transmission error).

66. Kirksey v. Kirksey, 8 Ala. 131 (1845) (holding that offer to provide support for deceased brother's family was gratuity).

67. Armstrong v. McGhee, Add. 261 (Westmoreland County Ct., Pa. 1795) (holding that if apparent contract for sale of horse was meant as joke, contract is void).

68. GUY DE MAUPASSANT, The Necklace, in THE COMPLETE SHORT STORIES OF DE MAUPASSANT 172, 177 (1941). 


\section{THE ATTEMPT TO CREATE ORDER}

Both literature and law impose an artificial order on chaotic reality. In literature, no matter how much an author might struggle to prolong disorder, the better to examine it, the literary form itself forces a beginning, a middle, and an ending onto every story. ${ }^{69}$ The hero cannot die of consumption in the first quarter of the novel, the police will catch the thief only after a long chase. By supplying an end, literature orders everything that comes before; but, within the construct of the physical text, the novel, play, or poem studies uncertainty and the sense of dread produced by uncertainty-is something going to happen?

Certainty is the great consolation of the law; right or wrong, every question has its answer. In law there are no inconclusive stories; every question is resolved, and every fact, every action, every word is understood and ordered. Law promises finality and repose. While legal precedent may be untidy and confusing, as one case overturns or expands another, each case has its own explicit justification and its link to the past. A judge's decision, when explained well, appears as inexorable as a string of actual and proximate causes lining up to unleash catastrophe. A well written decision leads a reader toward its own conclusion. As Benjamin Cardozo described the effect of John Marshall's opinions: "It is the inevitable progress of an inexorable force."

All of law, in a way, is a mechanism for accommodating the unknown and perilous future. Jerome Frank argues that law, like religion, is the product of the human need for certainty and security. "Man . . . driven by fear of the vaguenesses, the chanciness of life, has need of rest. Finding life distracting, unsettling, fatiguing, he tries to run away from unknown hazards ... [and] to postulate a legal system . . . free of the indefinite, the arbitrary and the capricious."71 Frank ties the desire to make law comprehensive and permanent to the child's early belief in the omniscience and omnipotence of the father, and the longing to regain that figure's lost authority. The desire to fashion an unwavering, perfect, and complete structure of law is the product of that same fundamental need. ${ }^{72}$ In law, the unpredictability of actual life is forced into

69. Examples of literary attempts to evade the linear form of narrative include SAMUEL BECKETT, WAITING FOR GODOT (1954); ITALO CALVINO, IF ON A WINTER'S NIGHT A TRAVELER (William Weaver trans., 1981) (1979); JULIO CORTAZAR, HOPSCOTCH (Gregory Rabassa trans., 1966) (1963); GABRIEL GARCIA MARQUEZ, CHRONICLE OF A DEATH FORETOLd (Gregory Rabassa trans., 1982) (1981).

70. Benjamin N. Cardozo, Law and Literature, 14 YALE REV. 699, 703 (1925).

71. JEROME FRANK, LAW AND TḤE MODERN MIND 196-97 (Anchor Books 1963) (1930).

72.

Despite advancing years, most men are at times the victims of the childish desire for complete serenity and the childish fear of irreducible chance. They then will to believe that they live in a world in which chance is only an appearance and not a reality, in which they can be free of the indefinite, the arbitrary, the capricious. When they find life distracting, unsettling, fatiguing, they long to rise above the struggle for existence; to be rid of all upsetting shifts and changes and novelties; to discover an uninterrupted connection between apparently disjunctive events; Id. at 19 . to rest in an environment that is fundamentally stable. 
an order that identifies cause and effect, innocence and blameworthiness. Legal rules allow participants to impose a structure on the unsteady progress of the world and to deny the power of the blind workings of chance. And while law is the imposition of a human-made order on actual events, literature is the artful induction of a created set of circumstances and its resolution in a reader. Through literature, a reader confronts the unappeasable anxiety that something is going to happen, but from a distance, and with a structure and coherence unavailable in life. Thus, the reader is allowed to experience vividly the apprehensiveness of actual life but is satisfied by conclusion in the end.

Viewed together, law and literature illuminate the fearful preoccupation with the future, a preoccupation that literature highlights but that law obscures. The examination of dread in law and literature does not provide a prescription for tort reform or a revolutionary reading of Heart of Darkness. ${ }^{73}$ But examining the undercurrent of dread reveals a hidden connection between two forms of human artifact. A study of literature in juxtaposition to law reveals a secret shape in the law, one hidden by the very forms that address it. The need for stability and order, denial of the uncertainty of actual life, is at the heart of the law. The study of law and literature together illuminates the preoccupation that the two disciplines address in different ways.

A reader must believe that he or she understands the past in order to have confidence in the present. Literature is awash in its own history, sometimes as explicit in its invocation of precedents as the law, sometimes subtle to the point of unrecognition. The same images, language, characters, and difficulties appear over and over in mutating combinations: a wicked stepmother, a dying child, a lost train ticket, lovers separated by distance. So, too, law brings the reassurance that every problem has been solved before. We have our answer. Dworkin invented an imaginary literary genre, the chain novel, as a metaphor to describe this aspect of legal precedent. In his view, each decision builds on and is constrained by the judgments of the past. ${ }^{74}$ In law, every problem is traced back to its earliest report. Every difficulty has its ancestral record. A 1988 property casebook cites Keeble v. Hickeringill from 1707, which in turn cites a case from 1410 , to make the point that a person may compete with another's trade but may not hinder it. ${ }^{75}$ Just as when Virginia Woolf's character Clarissa Dalloway quotes William Shakespeare who is himself retelling an old story, ${ }^{76}$

73. JOSEPH CONRAD, Heart of Darkness, in YOUTH AND TWO OTHER STORIES $S 1$ (Doubleday 1922).

74. DWORKIN, supra note 7, at 228-232.

75. JESSE DUKEMINIER \& JAMES E. KRIER, PROPERTY 23 (2d ed. 1988) (citing Keeble v. Hickeringill, 103 Eng. Rep. 1127 (1707) (citing 11 H. 4, 47 (1410))).

76. "There! the old lady had put out her light! the whole house was dark now with this going on, she repeated, and the words came to her, Fear no more the heat of the sun." VIRGNIA WOOLF, MRS. DALLOWAY 283 (1925). Clarissa quotes Shakespeare's Cymbeline:

Fear no more the heat $o^{\prime}$ the sun

Nor the furious winter's rages.

WILIAAM Shakespeare, CyMBeliNe, act 4, sc. 2, lines 258-60 (J.C. Maxwell, ed., Cambridge Univ. Press 1960). Shakespeare, in his turn, drew from Holinshed's account of the Battle of Luncarty and a Boccaccio 
and Jorge Luis Borges writes a story imagining a scholar who details the life of an imaginary author who reinvents Don Quixote, ${ }^{77}$ everything that ever was part of the law is still part of it-the Founders, the empire, a skull of egg-shell thinness, cows wandering through neighboring fields, peasant villages with banners flying. As time passes, and the case falls behind into history, its reality fades. Events take place in old-fashioned settings, involving buggies, polio, barrelmakers, squibs, and, again and again, railroads. The coercive aspect of the law dissipates into the past, so that the case is discussed as an allusion, or an example of a principle, not as the real solution that it once was. The imaginary replaces the real, and law and literature grow closer together.

\section{REVELATION: SOMETHING IS GOING TO HAPPEN}

This process of stripping away the inconsequential accretions of actual life is necessary to reveal a fundamental human preoccupation: the need to comprehend and conquer fate. In literature, as in law, there are no unimportant details. Layers of facts, observations, and emotions are made transparent to expose the essential core, the same impulses of fear and desire. Literature and law are united by the apprehension, expressed precisely by Oliver Wendell Holmes, that "certainty generally is illusion, and repose is not the destiny of man." "William Faulkner's character, Joe Christmas, expresses the same thought: "Something is going to happen. Something is going to happen to me."79 Examining law and literature together reveals the full outlines of the preoccupation, because literature exposes this fear while law controls it. Literature perpetually grapples with dread; law denies the arbitrariness of fate and struggles to solve, or cure, it. In different forms, each addresses the inescapable possibility, the pervasive uneasiness that something is going to happen, something terrible and unpredictable. Any single thoughtless moment may give actual and proximate causes an opportunity to align. Literature obsessively struggles with this fear, and law enters once that fear has been realized. So, viewed as two parts of a continuum, law and literature show how apprehension of the future creates a need for a human-imposed certainty, one that is fulfilled in part by the imposition of law. As Frank points out, the human desire for fixity and predictability persists even when wholly impractical. ${ }^{80}$

novella. Id. at Xv-xvi.

77. JORGE LUIS BORGES, Pierre Menard, Author of the Quixote, in LABYRINTHS 36 (Donald A. Yates \& James E. Irby eds. \& James E. Irby trans., 1964).

78. Oliver Wendell Holmes, The Path of the Law, in Collected Legal PAPERS 167, 181 (1920).

79. WILLIAM FAULKNER, LIGHT IN AUGUST 110 (1932).

80.

[T]he layman's ordinary practical needs would be seriously thwarted by an inelastic legal arrangement. A body of undeviating legal principles he would find unbearably procrustean. Yet paradoxically he and his lawyers, when they express their notions of a desirable legal system, usually state that they want the law to be everlastingly settled.

FRANK, supra note 71 , at 11 . 
Literature and law filter out the "irrelevant" to create final products that are reassuringly composed and dense with meaning. Even in the past, when the promise of apocalypse and judgment ordered all preceding events, law provided answers in the here-and-now. But the gods' intervention no longer explains fateful occurrences. Law satisfies the yearning for fulfillment, for remedy, the need to be made whole: the promise captured in the certainty of the final line of judgment: "It is so ordered." Now law shows us how danger enters the world and gives us our warnings; but those warnings are unavailing. Do not submerge or use near water. Keep out of the reach of children. Don't walk alongside a moving train on a dark night. ${ }^{81}$ Bargeman, stay on the barge ${ }^{82}$ Don't walk down the stairway in the dark. ${ }^{83} \mathrm{Be}$ careful hunting in the woods. ${ }^{84}$ Look long in both directions and listen hard for the sounding whistle when crossing the railroad tracks. ${ }^{85}$ Law making focuses attention on everyday situations which, in themselves, seem harmless and ordinary. But through the process of crisis, conflict, and resolution, law strips away the disguise of the commonplace and reveals the danger inherent in every circumstance.

\section{A. Awaiting Danger}

In contrast, literature fixes on suspense, arbitrariness, and peril. Sometimes the entire work will revolve on a sense of imminent upheaval, as in The Beast in the Jungle ${ }^{86}$ or in The Wild Palms. ${ }^{87}$ Literature examines dread as it unfolds, the vague fear that creeps into every expression of human concerns. The same words, something is going to happen, repeat in work after work: an incantation that at once invokes and wards off the inescapable.

Sometimes the feeling of suspense is one of erotic anticipation, a lust and fearful expectation mixed. "But the minute Shchagov had come in tonight, even while he was flirting with Dasha, she had known he had come to see her, and that something was going to happen."88 Or again: "He followed her to the kitchen. While she cooked they talked and he had another beer and she drank

81. See Erie R.R. v. Tompkins, 304 U.S. 64 (1938) (finding that under Pennsylvania law, railroad company is not liable for injuries sustained by man walking beside railroad tracks absent wanton or willful negligence on the part of the company).

82. See United States v. Carroll Towing Co., 159 F.2d 169 (2d Cir. 1947) (assessing liability for sinking barge).

83. See Wolf v. Kaufmann, 237 N.Y.S. 550 (Sup. Ct. 1929) (denying damages for tenement owner's negligence where evidence insufficient to prove hallway poorly lit).

84. See Summers v. Tice, 199 P.2d 1 (Cal. 1948) (holding two hunters jointly liable in accidental shooting of hunting party member).

85. See Pokoro v. Wabash Ry., 292 U.S. 98 (1934) (finding issue of negligence in railroad crossing accident to be question for jury); Baltimore \& Ohio R.R. v. Goodman, 275 U.S. 66, 70 (1927) (finding that, when crossing railroad track, person who "Telies upon not hearing the train or any signal and takes no further precaution ... does so at his own risk").

86. HENRY JAMES, The Beast in the Jungle, in THE PORTABLE HENRY JAMES 327 (Morton D. Zabel ed., Viking Press 1968) (1903).

87. WILLIAM FAULKNER, THE WILD PALMS (1939).

88. AlEKSANDR SOLZHENITSYN, THE FRST CIRCLE 290 (Thomas P. Whitney trans., 1968). 
wine. She wasn't hungry anymore. She knew something would happen and she was waiting for it, waiting to see what she would do." ${ }^{.89}$ The same feeling is expressed in poetry:

It was a lovely morning yesterday

and I think things have at last happened which will not go away. ${ }^{90}$

But these are rare occasions. Usually, the words predict some catastrophe. The premonition is accompanied with other indicia of disaster: smoking ruins, screeching car brakes, explosions, collapsing bridges, dogs barking in chorus in the middle of the night. "A screaming comes across the sky."191 Revelation comes through violence: “'Something's going to happen,' my father said, and he tapped his hands, both of them, on the metal window molding. He looked down at the street as if he was thinking. 'I wish I didn't feel that way."'92 A gleeful spirit hovers above a California highway, watching one car after another smash together. "Within the showers of broken glass, and fire that started up from leaking gas tanks across seven lanes, and showers of sparks, and pinging, flying metal, I began to hum, and to come alive, and to watch, and to wait for something to happen. ${ }^{.93}$ Children sense it. A young boy feels an unappeasable force rushing toward him. "He did not have to specify what kind of 'thing' had to 'happen'-sexual, religious, or mathematical, its end would be the same, cinders, whether caused by demonic intervention, burning petrol, or light from heaven centred by some metaphysical burning glass on them." ${ }^{\text {"94 }}$ Something draws nearer:

The sky is darkening like a stain;

Something is going to fall like rain,

And it won't be flowers. ${ }^{95}$

Attempts to make ready against sourceless disaster cannot succeed. A small band of explorers sets off on a journey across Australia, and from the moment they leave, it is inevitable that they will not return. But while they are still moving: "And now, at Jildra, something else was about to happen. Blacks scented it first upon the evening air, and dogs were half inclined to snarl, half to fool with one another." ${ }^{.96}$ The same feeling, now at a restaurant in London: "Susan, who feels scorn and fear at the sight of these preparations, fastens the

89. ANDRE DUBUS, Miranda Over the Valley, in SELECTED STORIES 1, 15 (1988).

90. ROBERT CREELEY, Je vois dans le hasard tous les biens que j'espere, in THE COLLECTED POEMS OF ROBERT CREELEY 86 (1982).

91. THOMAS PYNCHON, GRAVITY'S RAINBOW 3 (1973).

92. RICHARD FORD, WILDLIFE 158 (1990).

93. CAROLYN SEE, MAKING HISTORY 220 (1991).

94. A.S. BYATT, THE VIRGN IN THE GARDEN 342 (Vintage International 1992) (1978).

95. W.H. AUDEN, The Witnesses, in COLLECTED POEMS 71, 72 (Edward Mendelson ed., 1976).

96. PATRICK WHITE, Voss 183 (Penguin Books 1957). 
top button of her coat, and unfastens it. What is she making ready for? For something, but something different. ${ }^{, 97}$ A Russian family has squandered its fortune. They will lose their ancestral home, and its famous cherry orchard will be cut down to build new houses. But even before the lady of the house understands her situation, she senses disaster. "I I keep on waiting for something to happen, as if the house were going to collapse over our heads."'98

This dread-something is going to happen-invades even moments of peace or comforting routine, and stretches from childhood to old age. Clarissa Dalloway steps out of the house one morning to buy flowers for her party. As she waits to cross the street, "[s]he had a perpetual sense, as she watched the taxi cabs, of being out, out, far out to sea and alone; she always had the feeling that it was very, very dangerous to live even one day." ${ }^{199}$ And she had always felt that way, even on a bright morning in her youth:

How fresh, how calm, stiller than this of course, the air was in the early morning; like the flap of a wave; the kiss of a wave; chill and sharp and yet (for a girl of eighteen as she then was) solemn, feeling as she did, standing there at the open window, that something awful was about to happen .....$^{100}$

Disruption may come from any quarter. Passion has already transformed Wilbourne's and Charlotte's lives. He quit his medical internship, she left her husband and her two daughters. Now something else is going to happen. Wilbourne will discover that Charlotte is pregnant, and she will ask him to give her an abortion. Before he learns this, she says,

"All you have to do is be reasonably careful, isn't it? Boil the tools and so forth. Does it matter who you do it on?"

"They have to be fe--" Then he stopped. He looked at her, he thought swiftly, Something is about to happen to me. Wait. Wait. "Do it on?"101

Whatever will happen, it will disturb the entire existence of its target. Over the course of the novel, Enoch Emery feels his fate drawing closer, slowly but inevitably. He waits for it. "He knew something was going to happen to him. His blood stopped beating." "Then he knew that whatever was expected of him was only just beginning." "Enoch Emery knew now that his life would never be the same again, because the thing that was going to happen to him had started to happen." 102 One's own impulses, fateful tendencies, can be the source of

97. VIRGINIA WOOLF, THE WAVES 226 (1931).

98. ANTON CHEKHOV, THE CHERRY ORCHARD 36 (Jenny Covan trans., Brentano 1922) (1903).

99. WOOLF, supra note 76 at 11.

100. Id. at 3 .

101. FAULKNER, supra note 87, at 204.

102. FLANNERY O'CONNOR, WISE BLOOD 96, 100, 129 (Farrar, Straus \& Giroux 1990) (1952). 
the transformation. Over and over, Joe Christmas thinks, "Something is going to happen to me. I am going to do something." 103 People in the countryside are eager to cut off their own limbs, shedding them one by one. Their minds twist, and strange things happen: "We were all nervy with an unspoken anticipation. We were accelerating toward something and we didn't know what."104

Some welcome this metamorphosis by disaster. Without knowledge of what the "something" might be, its transformative power and its promise of annihilation tantalize the imagination. "When something real is about to happen to you, you go toward it with a transparent surface parallel to your own front that hums and bisects both your ears, making eyes very alert. The light bends toward chalky blue. Your skin aches. At last: something real."105

\section{B. Confronting Danger}

Law and literature are methods of response and consolation. Literature allows us to examine our fear, and through law, we can remedy the interventions of fate. The first lines of a case announce that something has happened. "On May 16, 1917, it became known in the city of Parsons that Agnes Smith, the Wife of Dr. Asa Smith, had been assaulted, and that a negro physician by the name of Robert E. Smith was suspected of the crime."106 "In July 1976, a small commercial aircraft crashed in the Scottish highlands during the course of a charter flight from Blackpool to Perth. The pilot and five passengers were killed instantly."107 "On May 10, 1979, Kevan Berkovitz, then a 2-month-old infant, ingested a dose of Orimune, an oral polio vaccine . ..."108 Law is an attempt to palliate the fear of what might happen, and the pain of what has happened.

For the novice, reading case law increases fear. Just as a medical student detects the signs of mortal disease in every patient, and a student of physics perceives light to move in a new way, the law student is plagued by a heightened sense of dread in daily life. Proximate causes lurk everywhere, ready to spring at the opportunity to form the inevitable circumstances of destruction. A woman waiting for the train stood a safe distance away from the tracks, but danger concealed itself in the small newspaper-wrapped package carried by the man running to jump aboard. ${ }^{109}$ That night seemed like every other night, innocent

103. FAULKNER, supra note 79 , at 97.

104. KATHERINE DUNN, GEEK LOVE 145 (1989).

105. PYNCHON, supra note 91 , at 754.

106. Taft v. Hyatt, 180 P. 213,214 (Kan. 1919) (denying reward to several parties who turned in fugitive).

107. Piper Aircraft Co. v. Reyno, 454 U.S. 235, 238-39 (1981) (finding that proper remedy was to order trial in Scotland).

108. Berkovitz v. United States, 486 U.S. 531, 533 (1988) (holding that Federal Tort Claims Act bars tort claims against federal government for approving polio vaccine).

109. Palsgraf v. Long Island R.R., 162 N.E. 99 (N.Y. 1928) (reversing jury's finding of negligence against railroad company when plaintiff was injured by scale that fell due to fireworks explosion). 
and ordinary; the shipkeeper watched television with his girlfriend and her family, the bridge operator was late coming back from the tavern. But earlier that night, rain and thaw had loosened the ice on the river. Ice jams wrenched loose and floated downstream, causing one ship to tear loose from its moorings, which crashed into another, and both ships were swept down the river. Because of a few small missteps, the shipkeeper failed to drop the anchor, the bridge rose too late, the towers collapsed, crew members were injured, and water and ice flooded the river-bank. ${ }^{110}$ Causes are waiting to converge.

Law defuses the fear of the unexpected and makes the uncertainty bearable. Senseless events are assigned their meaning. Law identifies the important facts, the injured and the injurer, and the moment at which a mishap could and should have been avoided. If only she had left the house ten minutes later. If only we had known the procedure's risks. If only they had taken the stairs. Literature searches for these inconspicuous, critical moments as well. Realizing that Prince Hamlet has secretly ordered their deaths, Guildenstern regrets the lost moment between two possibilities: " Our names shouted in a certain dawn ... a message ... a summons ... There must have been a moment, at the beginning, where we could have said-no. But somehow we missed it."'111

To respond to this deeply felt, pervasive human need for certainty, the law may rely upon a system of cause and fault, through which the arbitrary is made predictable and comprehensible. Fault orders the past into an understandable series of events that could have been prevented if only a wrongdoer had behaved correctly. Again and again, legal cases recount horrific sets of events that, seen in hindsight, seem almost impossible in their flawless execution of a string of accidents-but through law, we identify the reasons, the blame. A mudslide after a heavy rainfall damaged an ocean front home in Malibu, and the uphill landowner must pay. He could have prevented the damage. ${ }^{112}$ A house-guest severed tendons and nerves when the porcelain handle of a bathroom faucet cracked in his hand. His hostess is at fault. ${ }^{113}$ No misfortune is inexplicable: if a man fractures his kneecap on the Flopper amusement park ride, ${ }^{114}$ if a barrel falls out of a window, ${ }^{115}$ if a bartender slips on the ice, ${ }^{116}$ there is a reason. The legal process comforts the fearful by allocating fault. The process

110. Petition of Kinsman Transit Co., 338 F.2d 708 (2d Cir. 1964).

111. TOM STOPPARD, ROSENCRANTZ \& GUILDENSTERN ARE DEAD 125 (Henry Popkin ed., Grove Press 1978) (1967).

112. See Sprecher v. Adamson Co., 636 P.2d 1121 (Cal. 1981) (holding uphill landowner liable for breach of duty to exercise reasonable care to protect downhill owner).

113. See Rowland v. Christian, 443 P.2d 561 (Cal. 1968) (holding that failure to warn houseguest of dangerous faucet handle bears on whether tenant is liable).

114. See Murphy v. Steeplechase Amusement Co., 166 N.E. 173 (N.Y. 1929) (denying recovery of damages for injuries sustained in fall during amusement park ride).

115. See Byme v. Boadle, 159 Eng. Rep. 299 (Ex. 1863) (holding that barrel falling from window onto plaintiff is prima facie evidence of defendant's negligence).

116. See Adams v. Ferraro, 339 N.Y.S.2d 554 (App. Div. 1973) (holding tavern proprietor not liable for bartender's injuries because bartender was licensee not guest). 
reassures them that if they behave blamelessly, they will not cause something bad to happen. "But for" a wrongdoer's actions, an injury would not have occurred.

Yet the law need not rely only on notions of fault to allay pervasive feelings of dread, for strict liability systems also serve this purpose. Through such a legal regime, law gives its assurance that every misfortune will be addressed. Where danger is great and inescapable, law assigns guilt at the outset. Law reveals a yearning for restoration, a poignant and impossible goal. Its terminology promises impossibilities: knowledge of cause, blame, and righteousness; a return to a status quo ante, restitution, answers for all who pray for relief. Fiction suspends moments of fear and pain, examines every movement and angle and perpetuates them. The law promises resolution: a yes or a no.

Whether through fault or strict liability, the law may threaten as well as comfort, and so the law offers yet another doctrinal response to dread. Anyone may be caught by the law. At any time an action might lead to a disaster for which someone must be responsible. Holmes writes:

The law of torts abounds in moral phraseology. It has much to say of wrongs, of malice, fraud, intent, and negligence. Hence it may naturally be supposed that the risk of a man's conduct is thrown upon him as the result of some moral short-coming. But while this notion has been entertained, the extreme opposite will be found to have been a far more popular opinion;-I mean the notion that a man is answerable for all the consequences of his acts, or, in other words, that he acts at his peril always, and wholly irrespective of the state of his consciousness upon the matter. ${ }^{117}$

A moment's thoughtless action may expose an unexpected legal responsibility. A landlord must not fail to ensure that an apartment's shower door is constructed from safety glass, even if he cannot tell by looking whether the glass is tempered. ${ }^{118} \mathrm{~A}$ host cannot allow a guest to drive home drunk. ${ }^{119}$ So, because the law itself must not become a vehicle for arbitrary danger, the doctrine damnum absque injuria protects the innocent injurer by acknowledging that some losses imply no one's fault. Damnum sine injuria esse potest. There may be damage or injury inflicted without any act of injustice. ${ }^{120}$ This doctrine, an admission that something may happen for which there is no redress, is itself reassuring. The law does not punish the unavoidable or the inevitable. ${ }^{121}$ Thus,

117. OlIVER WENDELl HOLMES, THE COMMON LAW 65 (Mark DeWolfe Howe ed, Little, Brown \& Co. 1963) (1881).

118. See Becker v. IRM Corp., 698 P.2d 116 (Cal. 1985) (holding landlord strictly liable for injuries resulting from latent defect in premises).

119. See Kelly v. Gwinnell, 476 A.2d 1219 (N.J. 1984) (holding host who provided guest with liquor liable for injuries to third party due to guest's drunk driving).

120. BLACK'S LAW DICTIONARY 393 (6th ed. 1990).

121. 57A AM. JUR. 2D Negligence § 37 (1989). 
even those wrongs for which the law does not provide a remedy are encompassed within its framework. In its definition and declaration of what is inevitable, the law maintains its control over these occurrences.

The law purports to be a rational and systematic treatment of conflict. It provides a refuge for the injured and a guide for the timid. But literature's clues reveal the hidden force propelling the law, the apprehension of the future and the desire to control it. As much as law tries to explain them away, legal cases are an unhappy reminder of the three kinds of fate: the inevitable; the fateful tendencies each one of us brings into the world; and the accidental within the decrees of destiny. ${ }^{122}$ The law embraces each of these fateful circumstances. The inevitable: Petition of Kinsman Transit $\mathrm{Co}^{123}$ The fateful tendencies each one of us brings into the world: Steinhauser v. Hertz Corp. ${ }^{124}$ The accidental within the decrees of destiny: Palsgraf $\nu$. Long Island R.R. ${ }^{125}$ But despite whatever may happen, we have our answer, in those final lines uttered with such calm certainty. The judgment is affirmed and the appeal from the order denying a new trial is dismissed. The judgment is reversed. It is so ordered.

Robert Cover wrote about the feeling of imminent upheaval and the law's function in averting it. But for Cover, the catastrophe on the other side of the law was not arbitrary peril, but the Messiah. The coming of the Messiah is at once longed for and dreaded; the Messiah brings destruction as well as fulfillment. "The daring commitment is in this: One of law's usual functions is to hold off the Messiah. Messianism implies upheaval and fairly total transformation. Law ordinarily requires a cautious discernment among commitments ...."126 Law is the bridge between the actual world and a possible world: "[T] $]$ hat which holds our reality apart from our visions and rescues us from the eschatology that is the collision in this material social world of the constructions of our minds." ${ }^{27}$ By keeping the two moving worlds apart, the law holds off the Messiah and transformation.

Law holds us apart from our reality in another way, by allowing us to deny the arbitrary. Something is going to happen describes the threat of peril from

122. SIGMUND FREUD, The Theme of the Three Caskets, in CHARACTER AND CULTURE 67, 75 (Philip Rieff ed. \& C.J.M. Hubback, trans., 1963) (1913).

123. 338 F.2d 708 (2d Cir. 1964) (A thaw caused ice jams on the Buffalo River to float downstream, where they crashed into a negligently moored ship. The ship tore loose and floated downstream, where it crashed into and freed a properly moored ship. The ice and both ships were then swept downstream until they collided into a negligently-lowered bridge, resulting in a dam of the river that flooded riparian property for miles.) See supra note 110 and accompanying text.

124. 421 F.2d 1169 (2d Cir. 1970) (A minor car accident triggered a psychotic reaction in Cynthia Steinhauser, resulting in her hospitalization as an incurable schizophrenic.) See supra note 56 and accompanying text.

125. 162 N.E. 99 (N.Y. 1928) (Helen Palsgraf was injured by scales which fell due to the explosion of a small, newspaper-covered package carried by a man running to catch a train.) See supra note 109 and accompanying text. (1985).

126. Robert M. Cover, The Folktales of Justice: Tales of Jurisdiction, 14 CAP. U. L. REv. 179, 196

127. Cover, supra note 15 , at 10. 
the immediate world, from automobiles, exposed wires, rotten stairs. But these are only a shade of our real fear of the greater transformation to come: apocalypse. While literature admits and examines this fear, law restrains it with a showing of illusory control. By explaining and ordering the present day, the law provides relief from the eschatological impulse aroused by peril. Even the promise of an ecstatic apocalypse has an ominous undercurrent: "But as it is written, Eye hath not seen, nor ear heard, neither have entered into the heart of man, the things which God hath prepared for them that love him." ${ }^{\text {"28 }}$ Something is going to happen, whether arbitrary or God-decreed. Law is our response- to the Messiah, to the apocalypse, to the three fates or three Furies. The order we follow is our own invention: law, with its tools of cause, fault, intervention, in which the innocent are avenged and the foolish, punished. We have our answer.

But proximate cause is waiting, outside on the front stoop, waiting to happen. We are exposed to fortune. Don't go into the woods at night. Don't set out from home on an icy winter's morning. Stay away from the water's edge. Don't let the children stand near the stove. Something is going to happen. 